\title{
Risk Factors of Stunting Among Children in Some Areas in Indonesia: A Literature Review
}

\author{
Intan Gumilang Pratiwi ${ }^{1} \&$ Retno Wahyuningsih ${ }^{2}$ \\ ${ }^{1}$ Midwifery Departement, Health Polytechnic Ministry of Mataram, West Nusa Tenggara, Indonesia \\ ${ }^{2}$ Nutrition Departement, Health Polytechnic Ministry of Mataram, West Nusa Tenggara, Indonesia \\ Correspondence: Intan Gumilang Pratiwi, Midwifery Departement, Health Polytechnic Ministry of Mataram, \\ West Nusa Tenggara, Indonesia.
}

Received: June 29, 2018

doi:10.20849/ijsn.v3i3.468
Accepted: September 16, 2018

Online Published: September 19, 2018

URL: https://doi.org/10.20849/ijsn.v3i3.468

\begin{abstract}
Stunting is a malnutrition condition that caused by long-term insufficient nutrient intake. In 2010, the number of stunting in Indonesia reached $42.38 \%$. In 2013, the prevalence of stunting in Indonesia amounted to $37.2 \%$. The highest occurrence comes from East Nusa Tenggara with more than 50\% of the children are stunted. The method used in this paper is Literature Review. We use keyword Risk Factor and Stunting in online resources such as Science Direct, Proquest, PubMed, Google Scholar and another related website. Many risk factors affect stunting in Indonesia. Stunting is caused by multi-dimensional factors and not only caused by malnutrition factors experienced by pregnant women and children under five. Some of the cases described above have contributed to the high prevalence of stunting in Indonesia and therefore a comprehensive intervention plan is required to reduce stunting prevalence in Indonesia.
\end{abstract}

Keywords: risk factor, stunting

\section{Introduction}

Stunting is a malnutrition condition that caused by long-term insufficient nutrient intake. (Hafid, 2016).According to The Lancet's report in 2008, in the world, there are 178 million children aged less than five years old (toddlers) who are stunting with a large majority in South-Central Asia and sub-Saharan Africa. The prevalence of under-five stunting in 2007 worldwide was $28.5 \%$ and in all developing countries at $31.2 \%$. The Asian continent has a prevalence of under-five stunting by $30.6 \%$. The prevalence of under-five stunting in Southeast Asia was 29.4\%, higher than in East Asia (14.4\%) and West Asia (20.9\%) (Pormes, Rompas \& Ismanto, 2013).

In 2007 amounted to $36.6 \%$ children in Indonesia to experience stunting (Mulyati et al,2011). As much as 31.1\% in the group < 6 months, $34.2 \%$ in the age group of 6 to 11 months, $40 \%$ in the age group of 12 to 23 months, and $38.2 \%$ in the age group of 24 to 59 months. In 2010, the number of stunting in Indonesia reached $42.38 \%$ (Mulyati et al, 2011). In 2013, the prevalence of stunting in Indonesia amounted to $37.2 \%$. The highest occurrence comes from East Nusa Tenggara with more than 50\% of the children are stunted (Oliviana, Deandra, $\&$ Hubaidiyah, 2016).

While the prevalence of stunting (height-for-age Z-score less than two standard deviations below the global median, as defined by the 2006 World Health Organization Child Growth Standards among children under 5 years declined from 47\% in 1985 to $30 \%$ in 2011 globally, only minor improvements have been achieved in some of the poorest regions of the world, especially South Asia and sub-Saharan Africa. In recognition of the large disparities across the globe in the areas of early life nutrition and development, the World Health Assembly set a target to reduce by $40 \%$ the number of stunted children worldwide by 2025 . To reach this target, information on ways to alleviate stunting in each country is essential.

Indonesia's government is committed to reducing the number of stunting occurrence by $5 \%$ in 2015 . Internationally, Indonesia joins the Scaling Up Nutrition (SUN) Movement, a global movement with the purpose to give everyone their right to healthy and nutritious food. On September 2012, Indonesia launches the program called "Gerakan 1000 Hari Pertama Kehidupan" or First 1000 Days of Life or 1000 HPK. This movement aims to catalyst the increase of nutrition for a better future for Indonesian children. For this movement, government 
and stakeholders agreed on several specific interventions regarding nutrition to prevent and to deal stunting, such as breastfeed and complimentary food after breastfeeding promotion, free zinc-folate tablet or multivitamin and mineral for pregnant and nursing women, free micronutrient additive to children, food fortification, and medical care of malaria for pregnant women, babies, and children. In addition, interventions have also been done in other sectors such as clean and healthy lifestyle intervention (Oliviana et al., 2016).

To address this gap, we conducted a literature review of stunting risk factors in some areas In Indonesia.

\section{Method}

The method used in this paper is Literature Review. We use keyword Risk Factor and Stunting in online resources such as Science Direct, Proquest, PubMed, Google Scholar and another related website.

\section{Discussion}

Many risk factors affect stunting in Indonesia. We summarize from some research that has been done before in some areas In Indonesia. Erni Rukmana et al conducted a cohort study Risk Factors Stunting In Children aged 6-24 Months In Bogor West Java revealed that birth weight and father's education significantly related to stunting ( $\mathrm{p}<0.05$ ) with each OR being equal 4,192 and 1,807 with the direction of the comparable relationship straight and a risk factor for stunting. Children with low birth weight have a risk of 5.87 times for stunting. The results of research in Bali, West Java and NTT also showed low birth weight would be 2.21 times the risk to be stunting. The results of Eny Rukmana et al's study were only low dad's education. Low dad education will experience 1,807 times the risk of stunting children compared with high dad education. The results of this study in line with the results of research in Semarang and at Bangladesh that low father education is influential on the stunning event. Education a high chance to get a better job, which will impact on revenue and availability of food for his family. Education that father high is also associated with parenting patterns including the administration of vitamin A capsules, immunization complete, good sanitation and usage iodized salt. Dad's education is related to almost family income earned from father's income. (Rukmana, Briawan, \& Ekayanti, 2016)

Other studies In Brebes district, Central Java conducted a case-control study by Wiwien Fitri et al aimed to determine risk factors of stunting among children aged 12-24 months in Brebes District. The risk factors of stunting among children aged 12-24 months were low energy adequacy levels, low protein adequacy levels, low zinc adequacy levels, low birth weight and high exposure to pesticides. The highest risk was the high pesticide exposure. Multivariate results showed that the risk factors of stunting in children aged 12-24 months in Brebes subdistrict were low energy adequacy levels $(\mathrm{OR}=7.71 ; 95 \% \mathrm{CI}$ : 3.63-16.3; $\mathrm{p}=0.001)$, low protein adequacy levels (OR=7.65 ; 95\% CI:3.67-15.9, $\mathrm{p}=0.001)$; low zinc adequacy levels $(\mathrm{OR}=8.78 ; 95 \% \mathrm{CI}: 3.53-21.5, \mathrm{p}=0,001)$; low birth weight $(\mathrm{OR}=3.63 ; 95 \% \mathrm{CI}: 1.65-7.96 ; \mathrm{p}=0.002)$ and high exposure to pesticides (OR=8.48; 95\% CI:3.93-18.28; $\mathrm{p}=0,001)$. These three variables are contributing to stunting of $45 \%$. In addition, pesticide exposure is also a risk factor for stunting in this study. Previous research has concluded that children who are frequently exposed to pesticides are at risk of stunting $\mathrm{OR}=1,34 \mathrm{CI}=0.69-1.4$. While most of the subjects in this study are exposed to pesticide exposure.

Exposure to pesticides received by pregnant women can also make the baby stunting. Some types of pesticides are known as thyroid-disrupting chemicals (TDCs), which are chemicals in the environment that can disrupt the structure and function of the thyroid gland, disrupting the synthesis, secretion, transport, binding, and elimination of thyroid hormones, resulting in hypothyroidism. Hypothyroidism in pregnant women causes fetus/childbirth disturbance and is thought to be a major cause of increased cases of children with special needs, such as attention deficit hyperactivity disorder (ADHD) or autism. Research in the Netherlands proves that children born to mothers who suffer from hypothyroidism have a lower growth rate than the control group. In infants/children, hypothyroidism leads to impaired intelligence and decreases in their academic ability (Wellina, Kartasurya, \& Rahfilludin, 2016).

The case-control study Friska Meilyah and Muflihah Isnawati aimed to analyze the risk factors of stunting among 12 month old children at Purwokerto Village Patebon Subdistrict in Kendal District revealed that The bivariate analysis showed that risk factors of stunting on 12-month-old children at Purwokerto village were low birth length $(\mathrm{OR}=16,43 ; \mathrm{p}=0,002)$, prematurity $(\mathrm{OR}=11,5 ; \mathrm{p}=0,023)$ and first complementary feeding time $(\mathrm{OR}=4,24 ; \mathrm{p}=0,040)$ (Meilyasari \& Isnawati, 2014).

Infants born with short-term body lengths indicate poor nutritional intake during pregnancy so that fetal growth in the womb is not optimal. A good nutritional intake is important to support the growth of a child born with short-term lengths in order to obtain a normal body length with age. The results of this study indicate the age of 
pregnancy is a risk factor for stunting events of children aged 12 months. Growth in premature infants is delayed due to short gestational age and the presence of linear growth retardation in the womb. Infants born enough months if the intake of nutrients is less will also experience growth faltering. This will increase weight if coupled with exposure to infectious diseases. In contrast, premature infants who experience growth faltering if given adequate nutritional support then the normal growth pattern can be catch up. Early breastfeeding in infants younger than 6 months is one of the causes of a mother's failure to exclusively breastfeed. Other studies in India have shown that the provision of weaning food at an early age at the age of 0 to 2 months may increase the risk of stunting in infants aged 2-4 years. Early administration of weaning food increases the risk of infectious diseases such as diarrhea because of weaning food given not as clean and easily digested as breast milk. Diarrhea associated with failure to grow due to malabsorption of nutrients during diarrhea. If nutrients such as zinc and copper and water lost during diarrhea are not replaced, severe dehydration, malnutrition, failure to thrive and even death occur. In addition to the early delivery of weaning food, the delay of giving breastfeeding also causes growth and development of children under five become obstructed because the nutritional needs of children are not sufficient. In this study, there were two children in the case group and 1 child in the control group who received the first breastfed by the age of more than 6 months. (Meilyasari \& Isnawati, 2014)

Lestari, Margawati, \& Rahfiludin was aimed to analyze the risk factors for stunting among children between 6-24 months old at Penanggalan district, Subusallam, Aceh Province. The design was case-control study; the subjects were children between 6-24 months with 55 stunted and 55 normal.

Result of this study found the risk factors for stunting were low income of family (OR=8,5, 95\% CI: 2,68-26,89), suffering from diarrhea $(\mathrm{OR}=5,04,95 \% \mathrm{CI}: 1,84-13,81)$ and UTRI (OR=5,71, 95\% CI: 1,95-16,67), inadequate of energy (OR=3,09, 95\% CI: 1,02-9,39) and protein intake (OR=5,54, 95\% CI: 2,43-12,63), short stature of the parent $(\mathrm{OR}=11,13$, 95\%CI: 4,37-28,3), low birth weight ( $\mathrm{OR}=3,26$, 95\% CI: 1,46-7,31), not exclusively breastfeeding ( $\mathrm{OR}=6,54,95 \% \mathrm{CI}: 2,84-15,06)$, giving complementary feeding too early $(\mathrm{OR}=6,54,95 \% \mathrm{CI}$ : 2,84-15,06), and poor parenting style of feeding practices ( $\mathrm{OR}=4,59,95 \%$ CI: 2,05-10,25), child hygiene practices $(\mathrm{OR}=3,26,95 \% \mathrm{CI}: 1,46-7,31)$ and treatment of children practices (OR=2,46, 95\% CI: 1,13-5,34). Regression analysis showed that the dominant risk factor for stunting was short stature of the parent $(\mathrm{OR}=13,16$, 95\% CI: 3,72-46,52). The dominant risk factor for stunting was short stature of the parent. (Lestari, Margawati, \& Rahfiludin, 2014)

Oktarina and Sudiarti conducted a cross sectional study in Sumatera to analyze risk factors of stunting in underfive children age 24-59 months.

The data were collected by questionnaires and anthropometric assessment. Chi-square analysis and logistic regression were used to assess the association between risk factors and stunting in children. The result showed that prevalence of stunting among children was $44.1 \%$. The significant risk factors of stunting among subjects $(\mathrm{p}<0.05)$ were mother's height $(\mathrm{OR}=1.36)$, fat intake $(\mathrm{OR}=1.30)$, family size $(\mathrm{OR}=1.38)$, and drinking water resources $(\mathrm{OR}=1.36)$. The dominant factor that associated with stunting in children was a family size (OR=1.38).(Oktarina \& Sudiarti, 2014)

Toddlers from households with a large number of household members tend to experience stunting compared to toddlers from families with a sufficient number of household members. It can be concluded that there is a relationship between the number of household members and the incidence of stunting in infants. Toddlers from households with household members are at a greater risk of 1.34 compared to under-fives of households with a sufficient number of households. The results of this study are in line with previous studies showing the number of household members has a significant relationship to the incidence of stunting in infants. Tshwane University (2006) in his study also found a large family relationship with stunting events in infants. Stunting children come from families with more household members than normal children.(Oktarina \& Sudiarti, 2014)

Hafid Fahmi and Fahrul analyze the risk factors for Stunting of children aged 6-23 months in Regency of Bontoramba Jeneponto, South Sulawesi. The study found that the risk factors for stunting in children aged 6-23 months in District Bontoramba Jeneponto is due to low birth weight ( $\mathrm{OR}=4,018 ; 95 \% \mathrm{Cl} 1,714-9,420)$, age 12-23 months ( $\mathrm{OR}=2,688 ; 95 \% \mathrm{Cl} 1.646-4.390)$, maternal height $<150 \mathrm{~cm}(\mathrm{OR}=1,948 ; 95 \% \mathrm{Cl} 1,202-3,158)$, caregivers not washing hands with soap $(\mathrm{OR}=1,785 ; 95 \% \mathrm{Cl} 1,102-2,893)$, and incomplete basic immunization $(\mathrm{OR}=1,673 ; 95 \% \mathrm{Cl} 1,049-2,669)$. Low birth weight is the most dominant risk factor of stunting in this study.

Richard D semba et al was determine the effect of length of maternal and parental education on stunting in children under the age of 5 years In Indonesia and Bangladesh. Based on this study In Indonesia, greater maternal formal education led to a decrease of between 4,4 and $5 \%$ in the odds of child stunting (odds ratio per year $0,95,95 \%$ CI $0,946-0,954$ in rural setings; $0,950-0,961$ in urba settings); greater parental formal education 
led to a decrease of $3 \%$ in the odds of child stunting $(0,970,0967-0,974)$. In Indonesia, high levels of maternal and parental education were both assosiated with protective caregiving behaviours, including vitamin A capsule receipt, complete childhood immunisations, better sanitation, and use of iodised salt (all $p \leq 0.0001$ ) (Kumar \& Modi, 2008)

\section{Conclusion}

Many risk factors affect stunting in Indonesia. Stunting is caused by multi-dimensional factors and not only caused by malnutrition factors experienced by pregnant women and children under five.

Some of the cases described above have contributed to the high prevalence of stunting in Indonesia and therefore a comprehensive intervention plan is required to reduce stunting prevalence in Indonesia

\section{References}

Kumar, H.K.V.S., \& Modi, K.D. (2008). Effect of parental education on child stunting. The Lancet, 371(9627), 1836-7-author reply 1837. https://doi.org/10.1016/S0140-6736(08)60792-8

Hafid, F. (2016). Indonesian Journal of Human Nutrition. Indonesian Journal of Human Nutrition, 3(1), 42-53. https://doi.org/10.21776/ub.ijhn.2016.003.Suplemen.5

Lestari, W., Margawati, A., \& Rahfiludin, M.Z. (2014). Faktor Risiko Stunting pada Anak Umur 6-24 bulan di Kecamatan Penanggalan Kota Subulussalam Provinsi Aceh. Jurnal Gizi Indonesia, 3(1), 37-45. https://doi.org/10.14710/JGI.3.1.126-134

Meilyasari, F., \& Isnawati, M. (2014). Faktor Risiko Kejadian Stunting pada Balita Usia 12 Bulan di Desa Purwokerto, Kecamatan Patebon, Kabupaten Kendal. Journal of Nutrition College, 3(2), 16-25. Retrieved from https://media.neliti.com/media/publications/185456-ID-faktor-risiko-kejadian-stunting-pada-bal.pdf

Oktarina, Z., \& Sudiarti, T. (2014). Faktor Risiko Stunting Pada Balita (24-59 Bulan) Di Sumatera. Jurnal Gizi Dan Pangan, 8(3), 175-180. https://doi.org/10.25182/jgp.2013.8.3.177-180

Oliviana, P., Deandra, A., \& Hubaidiyah, F. (2016). Study on Stunting Prevention Program in Indonesia: A Literature Review, (2010), 318-323.

Rukmana, E., Briawan, D., \& Ekayanti, I. (2016). Faktor Risiko Stunting Pada Anak Usia 6-24 Bulan Di Kota $\begin{array}{llll}\text { Bogor. Media Kesehatan } \quad \text { Masyarakat Indonesia, } & \text { 12(3), }\end{array}$ https://doi.org/10.30597/MKMI.V12I3.1081

Wellina, W.F., Kartasurya, M.I., \& Rahfilludin, M.Z. (2016). Faktor Risiko Stunting pada Anak Umur 12-24 Bulan. Jurnal Gizi Indonesia, 5(1), 55-61. https://doi.org/10.14710/jgi.5.1.55-61

\section{Copyrights}

Copyright for this article is retained by the author(s), with first publication rights granted to the journal.

This is an open-access article distributed under the terms and conditions of the Creative Commons Attribution license (http://creativecommons.org/licenses/by/4.0/). 